\title{
SPERM TAIL FLEXIBILITY TEST: A SIMPLE TEST FOR SELECTING VIABLE SPERMATOZOA FOR INTRACYTOPLASMIC SPERM INJECTION FROM SEMEN SAMPLES WITHOUT MOTILE SPERMATOZOA
}

\author{
Jonathas Borges Soares, Sidney Glina, Nelson Antunes Jr, Roberta Wonchockier, \\ Andrea Giannotti Galuppo and Françoise Elia Mizrahi
}

\begin{abstract}
SOARES JB et al. - Sperm tail flexibility test: a simple test for selecting viable spermatozoa for intracytoplasmic sperm injection from semen samples without motile spermatozoa. Rev. Hosp. Clín. Fac. Med. S. Paulo 58(5):250-253, 2003.
\end{abstract}

PURPOSE: The objective was to describe the results of the injection of immotile spermatozoa with flexible tails when only immotile spermatozoa are present in the semen sample.

METHODS: A retrospective study was conducted to analyze the procedure results for 10 couples who participated in our intracytoplasmic sperm injection program. The sperm tail was considered flexible when it moved up and down independently of the head movement, and it was considered inflexible when the movement occurred together (tail plus head). The fertilization and pregnancy rate were analyzed.

RESULTS: The normal fertilization rate (presence of 2 pronuclei) was 30.3\% (40/132), and the abnormal fertilization rate (presence of less than or more than 2 pronuclei) was $6.81 \%(9 / 132)$. A total of 52 embryos were obtained with 9 transfer procedures performed (pregnancy rate: $11.12 \%$ ).

CONCLUSIONS: The sperm tail flexibility test (STFT) is an easy and cost-effective way for selecting viable immotile spermatozoa and can be used as an alternative method for determining the viability of spermatozoa. This test seems to be a simple and risk-free method when compared to the swelling test.

DESCRIPTORS: Intracytoplasmic sperm injection. Sperm. Flexible tail. Immotile sperm. Swelling test.

Even involving oligozoospermic or azoospermic men, intracytoplasmic sperm injection (ICSI) has produced acceptable fertilization and pregnancy rates. Palermo et al. (1995) obtained a fertilization rate of $63.9 \%$ and a pregnancy rate of $37 \%$ when the ICSI procedure was used as with couples in which the men presented severe male factor including a small number of motile sperm retrieved from the testis or epididymis ${ }^{1,2}$. It has been observed that the conventional seminal parameters have no influence in the results of ICSI procedures, except when only immotile spermatozoa are available ${ }^{3}$.
However, the use of live immotile spermatozoa leads to the possibility of fertilization, which does not happen when dead spermatozoa are injected.

Thus, it is crucial to differentiate live immotile spermatozoa from dead spermatozoa when only immotile spermatozoa are available. The most commonly used test with this purpose is the swelling test ${ }^{4}$. However the swell-

From the Human Reproduction Unit, Albert Einstein Jewich Hospital - São Paulo/SP, Brazil.

Received for publication on February 04, 2003. ing test, used as a test to determine cell viability, is still controversial. There is evidence that this test is not totally reliable for predicting sperm viability and that the standardized solutions used can be harmful to the spermato$\mathrm{zoa}^{5,6}$.

Previously, we observed that when we used semen samples that presented only immotile spermatozoa, the injection of those spermatozoa with flexible tails (tail flexibility when touched with the ICSI pipette) resulted in acceptable fertilization rates. We considered this data as possible evidence of cell viability. 
The aim of this work is to describe the results of 10 ICSI cycles for which the injection of exclusively immotile spermatozoa with flexible tails was performed.

\section{METHODS}

Among 1283 cycles in which ICSI done from January 1997 to October 2001, in 10 cycles the men presented samples containing only immotile spermatozoa, as follows: 4 were azoospermic men due to vasectomy, 5 had nonobstructive azoospermia, and 1 did not get the sample. All patients underwent percutaneous epididymal sperm aspiration (PESA), testicular sperm aspirations (TESA) and/or testicular sperm extraction (TESE) ${ }^{7,8}$. The average age of the women was 34 years (range, 31 to 40 years), and the average age of their partners was 44 years (range, 38 to 51 years). In the women after hypophysis blockage with the GnRh agonist (GnRh-a), human menopausal gonadotrophin (hMG), follicle stimulating hormone (FSH) or recombinant FSH was used to stimulate folliculogenesis. Follicular development was followed by echography. When the follicles reached a maximum diameter of 20 to $22 \mathrm{~mm}$, human chorionic gonadotrophin (hCG) was administrated. Follicular aspiration was performed under the guidance of transvaginal ultrasound 36 hours after the hCG injection. The follicular fluid was collected in closed system in $15 \mathrm{~mL}$ tubes filled with $2 \mathrm{~mL}$ of Dulbeco's phosphate buffer solution plus $10 \mathrm{IU} /$ $\mathrm{mL}$ heparin at $37^{\circ} \mathrm{C}$. The presence of spermatozoa was verified by optical microscopy. The material was kept at $37{ }^{\circ} \mathrm{C}$ until the moment of the ICSI procedure. Sperm tail flexibility was verified just before the injection. The spermatozoa was considered flexible when the tail moved up and down independently of the head movement, and it was considered inflexible when the movement occurred together (tail plus head) (Figure 1). The ICSI procedure was performed in a Petri dish (Falcon 3002) in a $5 \mu \mathrm{L}$ drop of modified human tubal fluid (HTF) (Irvine Scientific 9962) supplemented with 5\% bovine serum albumin under mineral oil (Sigma M8410). The ICSI procedure was performed according to the $\mathrm{Hu}$ man Reproduction Unit protocol'

\section{RESULTS}

In this study, the results of 10 ICSI cycles using immotile spermatozoa with flexible tails were evaluated. A total of 177 oocytes were retrieved, of which 132 were mature and were injected. All the oocytes were injected with immotile spermatozoa with flexible tails. The normal fertilization rate (presence of 2 pronuclei) was $30.3 \%$
(40/132), and the abnormal fertilization rate (presence of less than or more than 2 pronuclei) was $6.81 \%(9 / 132)$. After the injection, 52 embryos were obtained; 36 were grade I or II, and 16 were grade III or IV, according to the Veeck morphological classification ${ }^{10}$. Third-four embryos were transferred, with an average of 3.4 embryos per patient. In 9 transfer procedures, 1 pregnancy was obtained (pregnancy rate: $11.12 \%$ ). One patient had all her embryos cryopreserved because she had ovarian hyperstimulation syndrome. The embryos were divided into groups and thawed twice, with transfer in 2 different cycles without pregnancy.

\section{DISCUSSION}

The immobility of the spermatozoa can indicate cell death or just a structural alteration that does not compro-

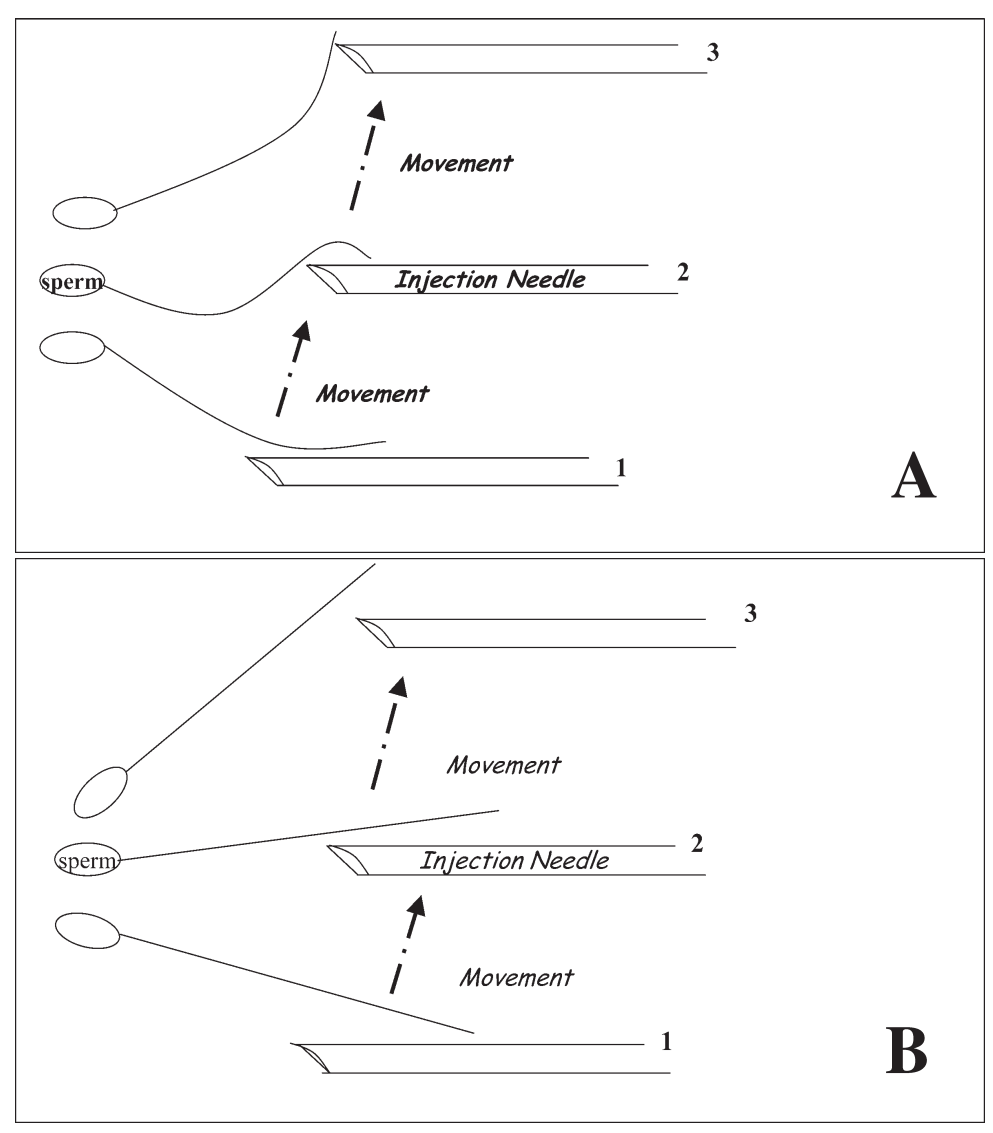

Figure 1 - A) Sperm tail flexibility test (STFT)-positive result; B) STFT-negative result. 
mise the possibility of fertilization. However, the methods used today to select immotile but viable spermatozoa do not have absolute efficacy ${ }^{5,11}$.

The swelling test can be used to select viable sperm; however, the results are still controversial. According to Liu et al. (1995), the absence of motile spermatozoa is one of the most important factors related to the reduction of the pregnancy rate after ICSI ${ }^{12}$. Several authors have performed studies regarding the advantages and disadvantages of the swelling test ${ }^{5,6}$. Tsai et al. (1970) suggested that the swelling test should be used to select viable spermatozoa for ICSI when the samples present only immotile spermatozoa ${ }^{11}$. Liu et al. (1997) also presented this test as an efficient method for selecting vi- able spermatozoa ${ }^{6}$. However, Lin et al. (1998) showed that the hyposmotic test was not able to predict the viability of spermatozoa after a freezing/ thawing procedure ${ }^{13}$. Tsai et al. (1997) demonstrated that the hyposmotic swelling test standardized by the World Health Organization could be harmful to the spermatozoa ${ }^{11}$. Furthermore, the swelling test is a time-consuming process that adds extra steps to the assisted fertilization procedure.

In our work, the fertilization rate was $30.3 \%$ when the selection of the spermatozoa was made by tail flexibility, and the pregnancy rate resulting after fresh embryo transfer was $11.12 \%$. Our results are similar to those reported in the literature. Nagy et al. (1998) reported a fertilization rate of
$21 \%$ when immotile spermatozoa selected by swelling test were used ${ }^{14}$. Sallam et al. reported $30.1 \%$ of fertilization rate when immotile spermatozoa collected by TESA were used ${ }^{5}$. Vandervorst et al. found a similar result; they reported a fertilization rate of $34.4 \%$ using immotile spermatozoa collected by masturbation ${ }^{15}$. Ron-El et al. ${ }^{16}$ reported only a $3 \%$ fertilization rate when immotile spermatozoa were used.

The sperm tail flexibility test (STFT) is an easy and cost-effective way to select viable immotile spermatozoa and can be used as an alternative method for determining the viability of spermatozoa. The STFT seems to us a simpler and more risk-free method than the swelling test.

\section{RESUMO}

SOARES JB e col. - Teste de flexibilidade da cauda do espermatozóide: um teste simples para seleção de espermatozóides viáveis para injeção intracitoplasmática de espermatozóide a partir de amostras de sêmen sem espermatozóides móveis. Rev. Hosp. Clín. Fac. Med. S. Paulo 58(5):250-253, 2003.

OBJETIVO: Descrever os resultados da injeção de espermatozóides imóveis com cauda flexível quando somente estavam presentes nas amostras espermatozóides imóveis.

MÉTODOS: Estudo retrospectivo analisando os resultados dos procedi- mentos de injeção intracitoplasmática de espermatozóide, de 10 casais, realizados no nosso centro. A cauda do espermatozóide era considerada flexível quando esta se movia para cima e para baixo independente do movimento da sua cabeça, e era considerada rígida quando o movimento acontecia em bloco (cabeça e cauda). Os parâmetros de avaliação foram taxas de fertilização e gestação.

RESULTADOS: A taxa normal de fertilização (presença de 2 pró-núcleos) encontrada foi $30,3 \%(40 / 132)$ e a taxa de fertilização anormal (presença de menos ou mais de 2 pró-núcleos) foi $6,81 \%$ (9/132). No total foram obtidos
52 embriões e foram realizados 9 procedimentos de transferência, a taxa de gestação encontrada foi de $11,12 \%$.

CONCLUSÕES: O teste de flexibilidade da cauda do espermatozóide é um método fácil e de baixo custo para avaliação da viabilidade de espermatozóides imóveis e pode ser usado como um método alternativo de determinação da viabilidade de espermatozóides. Esse teste nos parece ser mais simples e com menor risco quando comparado ao Swelling Test.

DESCRITORES: ICSI. Espermatozóides. Cauda flexível. Espermatozóides imóveis. Swelling test.

\section{REFERENCES}

1. PALERMO GD, COHEN J, ALIKANI M et al. - Intracytoplasmic sperm injection: a novel treatment for all forms of male factor infertility. Fertil Steril, 1995, 63(6): 1231-40.
2. MAGDAR I, SEIDMAN DS, LEVRAN D et al. - Micromanipulation improves in vitro fertilization results after epididymal or testicular sperm aspiration in patients with congenital absence of the vas deferens. Human Reprod 1996; 11:2151-4. 
3. JEYENDRAN RS, VAN DER VEM HH, PEREZ-PELAEZ BG et al. - Development of an assay to assess the functional integrity of the human sperm membrane and its relationship to other semen characteristics. J Reprod Fertil 1984; 70:219-28.

4. WORLD HEALTH ORGANIZATION laboratory manual for the examination of human semen and sperm-cervical mucus interaction. $4^{\text {th }}$ ed. Cambridge, Cambridge University Press, 1999.

5. SALLAM HN, FARRAG A, AGAMEYA AF et al. - The use of a modified hypo-osmotic swelling test for the selection of viable ejaculated and testicular immotile spermatozoa in ICSI. Human Reprod 2001;16(2):272-6

6. LIU J, TSAI YL, KATZ E et al. - High fertilization rate obtained after intracytoplasmic sperm injection with $100 \%$ no motile spermatozoa selected by using a simple modified hypo-osmotic swelling test. Fertil Steril 1997; 68(2):373-5.

7. TEMPLE-SMITH PD, SOUTHWICK GJ, TROUNSON AO et al. - Human pregnancy by in vitro fertilization (IVF) using sperm aspirated from the epididymis. J In Vitro Fert Embryo Transf $1985 ; 2: 119-22$.

8. CRAFT I, TSIRIGOTIS M, BENNETT V, et al. - Percutaneous epididymal sperm aspiration and intracytoplasmic sperm injection in the management of infertility due to obstructive azoospermia. Fertil Steril 1995; 63:1038-42.

9. MIZRAHI FE, SOARES JB, WONCHOCKIER R, et al. Determinação da qualidade embrionária e correlação com sua taxa de implantação em um programa de Reprodução Assistida. J Bras Reprod Assist 1999; 3:14-9.
10. VEECK LL AND JONES JR HW - Atlas of the Human Oocyte and Early Conceptus. Cambridge, Cambridge University Press, 1991. v.2.

11. TSAI YL, LIU J, GARCIA JE et al. - Establishment of an optimal hypo-osmotic swelling test by examining single spermatozoa in four different hypo-osmotic solutions. Human Reprod 1997; 12(5):1111-1113.

12. LIU J, NAGY Z, JORIS H et al. - Analysis of 76 total-fertilizationfailure cycles out of 2732 intracytoplasmic sperm injection cycles. Human Reprod 1995; 10:2630-6.

13. LIN MH, MORSHEDI M, SRISUMBUT C et al. - Plasma membrane integrity of cryopreserved human sperm: an investigation of the results of the hypo-osmotic swelling test, the water test and eosin-y staining. Fertil Steril 1998; 70:114855 .

14. NAGY ZP, VERHEYEN G, TOURNAYAL H et al. - Special applications of intracytoplasmic sperm injection: the influence of sperm count, motility, morphology, source and sperm antibody on the outcome of ICSI. Human Reprod 1998; 13(suppl 1):143-54

15.VANDERVORST M, TOURNAYE H, CAMUS $M$ et al. - Patients with absolutely immotile spermatozoa and intracytoplasmic sperm injection. Human Reprod 1997; 12(11):2429-33.

16.RON-EL R, STRASSBURGER D, FRIEDLER S et al. - Repetitive ejaculation before intracytoplasmic sperm injection in patients with absolute immotile spermatozoa. Human Reprod 1998; 13(3):630-3 